\title{
Does recent fire activity impact fire-related traits of Pinus halepensis Mill. and Pinus sylvestris L. in the French Mediterranean area?
}

\author{
Bastien Romero $^{1}$ (D) $\cdot$ Anne Ganteaume ${ }^{1}$
}

Received: 5 August 2020 / Accepted: 26 October 2020 / Published online: 16 November 2020

(C) INRAE and Springer-Verlag France SAS, part of Springer Nature 2020

\begin{abstract}
- Key message Climate change will induce a change in fire frequency in Mediterranean region and that could impact fireadapted plant species. We showed that fire-related traits of some pine species are strongly related to other factors than fire but the recent fire history has nonetheless an impact on the variation of key traits for different fire adaptive strategies. - Context In fire-prone Mediterranean areas, climate change is expected to exacerbate the fire pressure on ecosystems, altering the current fire regime and threatening species if they cannot acclimate.

- Aims Studying intraspecific variations of some fire-related traits in relation to variation in recent fire activity is thus an important step to better understand if this acclimation is possible.

- Methods We measured structural (bark thickness, shoot bulk density, self-pruning, leaf surface to volume ratio) and functional (serotiny level for Pinus halepensis only) traits in two pines species (Pinus halepensis and Pinus sylvestris) commonly found in southeastern France and that present different fire-adaptive strategies (resilience vs resistance, respectively). Populations were sampled according to different fire frequency modalities ( 0 vs 1 to 2 fires) along a geographical gradient, measuring numerous environmental and plant characteristics to be used cofactors in the analyses.

- Results As expected, trait variation was strongly linked to environmental and tree characteristics as well as to ontogeny overriding the effect of fire modalities, even though using integrative models with random effect. However, fire modalities had an impact on the variance of some key fire-related traits of Pinus halepensis.

- Conclusion This study will help to anticipate the future response of these Mediterranean pine species and further underlines the importance of investigating chemical traits, flammability, and genetic variation of highly heritable traits, such as serotiny.
\end{abstract}

Keywords Fire adaptive strategies $\cdot$ Structural and functional traits $\cdot$ Fire frequency $\cdot$ Serotiny $\cdot$ Phenotypic diversity

\section{Introduction}

Forest fires have been one of the most important contributing factors to Mediterranean ecosystem dynamics for millennia

\section{Handling Editor: Paulo Fernandes}

Contributions of the co-authors Bastien Romero and Anne Ganteaume conceived and designed the experiments.

Bastien Romero performed the experiments and analyzed the data.

Bastien Romero wrote the paper and Anne Ganteaume has significantly improved the manuscript.

Bastien Romero

bastien.romero@inrae.fr

Anne Ganteaume

anne.ganteaume@inrae.fr

1 Institut national de recherche pour l'agriculture, l'alimentation et l'environnement (INRAE), UMR Recover, Aix-en-Provence, France
(Bond and van Wilgen 1996; Pausas and Keeley 2009), exerting a high selective pressure on species (Bond and Keeley 2005; Keeley et al. 2011; Pausas and Ribeiro 2017). In fire-prone Mediterranean areas, the long-term fire history has led to numerous plant fire adaptations (Ne'eman et al. 2012). However, these adaptations depend more on the fire regime than on the fire itself (Keeley et al. 2011). A fire regime is defined by fire intensity and frequency, among other characteristics. The predominant parameters that induce different fire adaptation strategies (e.g., fire resistance or resilience) involve different fire-related traits (Keeley et al. 2011). These traits improve tree or population survival in case of fire, increasing the species' fitness (Fernández-García et al. 2020; Lamont et al. 2011, 2013).

In the Mediterranean basin, the parameters that characterize the fire regime have been changing in recent decades, mostly due to the increasing temperatures that induce higher fire activity (Oliveira et al. 2012; Moreno et al. 2014; Quintano et al. 
2015). This trend is likely to continue, leading to an increase in fire frequency and severity (Fargeon et al. 2017; Turco et al. 2018), ultimately changing the current fire regime and thus affecting the fire-prone Mediterranean ecosystems, if species' resilience or resistance capacity is exceeded (FernándezGarcía et al. 2019); Pausas and Keeley 2014; Pausas 2015a). Moreover, changes in fire risk, especially in the northern part of the French Mediterranean region and at higher elevations where species are rarely exposed to high-intensity fires (e.g., crown fires), will induce a change in the boundaries of species' bio-climatic areas (Fréjaville and Curt 2015). In fact, if surface fires tend to become more intense and turn into crown fires, or if crown fires become too frequent, both fire-resistant and fire-embracer species could be threatened assuming that their specific fire-related traits do not evolve accordingly.

These fire-related traits, depending on the species' adaptation to fire, improve the survival of trees to fire; they can be structural, functional, or even chemical. Fire "embracer" species (i.e., resilient species) are adapted to infrequent highintensity fires, characterized by stand-replacement events (e.g., crown fires). Over time, these species have acquired fire-related traits that enhance their post-fire regeneration, such as serotiny (canopy seed bank in serotinous cones) (He et al. 2011; Pausas 2015a). Seeds stored in serotinous cones are protected from rising temperatures and thus present a major advantage for fire-embracer species in case of intense fire. The high temperature emitted by the fire induces a heat shock allowing the cones to open, leading to the seed release (Ne'eman et al. 2004; Tapias et al. 2004). After the fire, the seeds are released into an environment without competition for light, water, and nutrients as most plants are burned, allowing the seedlings to grow in better environmental conditions. Given its primordial implication in the fire adaptive strategy of numerous fire-embracer species, serotiny is one of the most studied functional fire-related traits (Causley et al. 2016; Keeley et al. 2011; Lamont and Enright 2000; Lamont 2020; Martín-Sanz et al. 2016). In addition, many species have seed germination stimulated by smoke or high temperature (Tieu et al. 2001), or plant resprouting (Ne'eman et al. 2012). Some of these species have traits that enhance their flammability, such as the dead fuel retention in the canopy, specific leaf physical characteristics (e.g., thin and long needles), or chemical compounds such as terpenes (Romero et al. 2019). Higher flammability is an ecological advantage for embracer species because their post-fire regeneration is based on rapid growth in an enriched environment where competition is reduced, according to the "Born to Burn" hypothesis (Mutch 1970; Bond and Midgley 1995). In contrast, fire "evader" species present traits that mitigate the effects of recurrent, medium- to low-intensity fires (heat shock for instance), such as self-pruning, thick bark, deep rooting, or other traits that decrease shoot flammability (e.g., thick and short needles), allowing them to resist such fires. These species are adapted to surface fires for instance (Fernandes et al. 2008). It is worth noting that some species can present both types of strategies (e.g., Pinus canariensis C.Sm ex DC., 1825) due to their living conditions (e.g., types of fire regime; Climent et al. 2004).

Previous studies on fire-related traits in fire-prone ecosystems have mostly focused on differences among species, especially between different adaptive strategies (embracer vs evader) (Ne'eman et al. 2012; Pausas et al. 2004; Paula et al. 2009). Only a few studies (e.g., Budde et al. 2014; HernándezSerrano et al. 2014; Pausas et al. 2012) have focused on the intraspecific variability of such traits in relation to fire recurrence. However, these studies were based on a fire recurrence of three or more fires over a 70-year period or over a wide area (at the scale of a region or a country in Pausas et al. 2012 and Budde et al. 2014) and only considered a few environmental variables in order to explain trait variation. In fact, traits considered being fire-related can also vary according to several other variables (e.g., weather, soil nutrient, competition for light, plant age, topographic site conditions). When considering the recent fire history (the last five-six decades), especially in areas where the number of fire events is low, it is difficult to disentangle the effects of fire on trait variation from the effects of environmental conditions. Regarding serotiny, one of the most studied fire adaptations, some authors noted an increase in serotinous cones in the F1 generation of Pinus contorta (Bol., 1866) and Pinus banksiana (Lamb., 1803) after only a single fire event (Perry and Lotan 1979; Teich 1970), showing how strong the selective impact of fire on this trait is. Further works (Castellanos et al. 2015; HernándezSerrano et al. 2014) found that heritability of serotiny in P. halepensis was relatively high, $10 \%$ in natural populations against $20 \%$ in common garden and found a high quantitative genetic differentiation among populations from different locations, suggesting adaptation process. Serotiny is known for its high phenotypic diversity among species, populations, or geographical areas, and it is hypothesized that this variability may not be entirely due only to fire (Espelta et al. 2011; He et al. 2012; Ne'eman et al. 2012; Tapias et al. 2004; Voltas et al. 2008). For example, Martín-Sanz et al. (2017) confirmed that water availability had a crucial impact on cone opening and Cruz et al. (2019) pointed that serotiny level was higher from young mother trees. Moreover, Pausas (2015b) underlined that most studies focused on differences between fire-related traits whereas trait variance is very important to consider in order to fully understand trait variation mechanisms. Up to now, studies that deal with both fire adaptive strategies and take into account a range of fire frequencies as well as environmental and tree characteristics to explain trait variations and to possibly stress difference between strategies, are lacking.

In order to address these gaps, the present study examines the differences in relevant fire-related traits in two common 
Mediterranean pine species between areas that have been subjected to a range of fire frequencies (i.e., recent presence or absence of fire in a given site) over the last few decades (i.e., recent fire history). The objectives of the present study were (i) to assess these species' capacity to adapt their fire-related traits to different fire frequencies and (ii) to determine the effect of environmental and tree characteristics and ontogeny (i.e., different development stages) on the distribution of firerelated traits in order to disentangle the effect of fire from other environmental or tree characteristics. We expect the variation in the species' fire-related traits to be related to the variation in the number of recent fire events. Better understanding this process will help in predicting plant species dynamics in response to changes in fire regime in Mediterranean ecosystems in the framework of ongoing global change. Indeed, if these species do not acclimate and/or adapt to this change, an increase in population mortality is expected, increasing the risk of fire throughout the study area (Dupire et al. 2019).

\section{Material and methods}

\subsection{Area and species studied}

Populations were sampled in the North and in the South of the Provence area in the French Mediterranean region (Baronnies Provençales Natural Regional Park and Aix-en-Provence/ Marseille area, respectively; Fig. 1). We decided to split the Provence area into two different zones in order to account for a gradient of climatic conditions (temperature and precipitation) because of the higher elevation in the North (on average $650 \mathrm{~m}$ ) compared to the South (on average $400 \mathrm{~m}$ ). The northern part of the study area was mostly characterized by a supraMediterranean climate (Emberger 1963) and acidic soil, especially in the most elevated areas to the North, where the vegetation is mainly composed of a mixture of $P$. halepensis (Mill.1768), Quercus pubescens (Willd. 1796), and P. sylvestris (Mill., 1768) and Fagus sylvatica (L. 1753) in the most northerly part of the area. The South is characterized by a meso-Mediterranean climate and limestone soil where the most common tree species are P. halepensis, Quercus pubescens, Quercus ilex (L. 1753), and P. sylvestris at higher elevations.

In the present study, we focused on obligate seeders with post-fire recruitment that is solely based on seeds (Nuñez et al. 2003). This facilitates faster generation turnover and makes the species more sensitive to changes in fire frequency (Verdú and Pausas 2007). We sampled populations of two species commonly found in the study area (Pinus halepensis and Pinus sylvestris) and that present two different adaptive strategies to fire. Pinus halepensis is a fire-embracer species (Ne'eman et al. 2004) adapted to infrequent stand-replacing fires. This species is dominant in the study area, especially in the southern part and at low elevations. Its post-fire regeneration strategy is based on seed development and storage in serotinous cones (forming a canopy seed bank) that stay closed pending the arrival of a fire. In this species, serotiny and early flowering (occurring at approximatively 5 years old) reflect its fire-embracer strategy as these characteristics allow for successful post-fire recruitment (Fernandes et al. 2008; Tapias et al. 2004). With global change, $P$. halepensis' biogeographical area is expected to expand to the North of the study area, which is the current boundary of its distribution area (Bede-Fazekas et al. 2014).

Pinus sylvestris is an evader species (Fernandes et al. 2008; Granström 2001), more adapted to recurrent low- to mediumintensity fire, corresponding to surface fires (Angelstam and Kuuluvainen 2004; Brumelis et al. 2005). This species has developed traits that allow for resistance to such fires (e.g., tree height, self-pruning, or thick bark; Fernandes et al. 2008). The geographical distribution of this species is related to lower temperatures and/or higher elevations compared to that of $P$. halepensis, and populations are very well established in the most northerly part of the study area and at higher altitudes in the South (which is the boundary of its biogeographical area, see Fig. 2 in annex).

\subsection{Sampling plan}

For each geographical location and species, populations were sampled (Romero and Ganteaume 2020), according to the fire modality, at unburned areas ("No-fire" modality, i.e., no fire for the last 47-59 years, depending on the sub-region) and at areas that have experienced a fire ("Fire" modality; i.e., one fire or more for the last 47-59 years, depending on the subregion). The recent fire history of the northern sub-region was reconstructed using the regional fire database Prométhée that has been recording fires since 1973 and by using satellite images to outline the fire perimeters (QGIS software). As southern Provence is more impacted by fires, another database (ONF/DDTM database) whose fire records began in 1959, was used to establish the recent fire activity and select the sample sites. Given that northern Provence and the areas located at high elevations in the South are still relatively unaffected by fires, the "Fire" populations sampled in these areas had only undergone one fire event at the time of the sampling. In the South, when populations had undergone more than one fire event (i.e., $P$. halepensis populations), we selected populations that had at least a 10 -year interval between fire events to be sure that the trees that regenerated after the most recent fire were sexually mature (Santos del Blanco et al. 2010). All of the sampled P. halepensis' "Fire" populations had experienced stand-replacing fires and had thus been completely burned during these events. In contrast, for the P. sylvestris' 


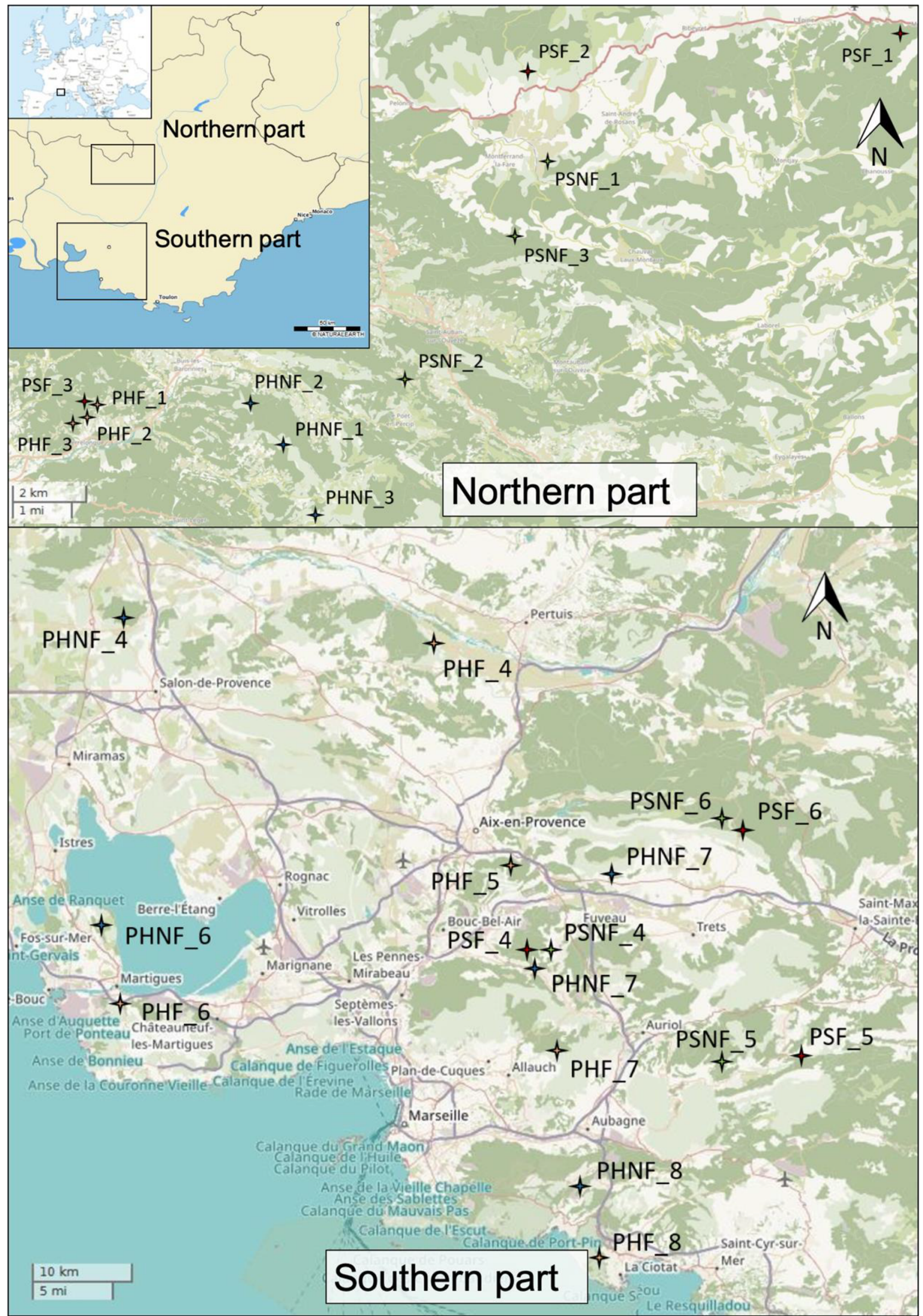

Fig. 1 Map of the study area with a focus on the northern and southern sampling plots (PH, P. halepensis; PS, P. sylvestris; F, "Fire" populations; NF, "No-Fire" populations) 
"Fire" populations, the past fires did not kill all of the trees, inducing a post-fire recruitment based solely on tree survival.

Within each sub-region, great care was taken to ensure that the population sampling sites were selected with environmental conditions and population characteristics that were as homogeneous as possible (e.g., nature of the soil, elevation, exposure, basal area, precipitation, floristic composition) (see Table 3 and Table 4 in annex) in order to avoid potential confounding environmental factors. Furthermore, in order to avoid geographical segregation, the selected pairs of "Fire" and "non-fire" populations were between 2 and $8 \mathrm{~km}$ apart from each other. All of the trees of the same species were sampled in the same age range $(22.5 \pm 2.2 P$. halepensis and $20.3 \pm 6.0$ for $P$. sylvestris) only considering mature (i.e., if cones were observed in the canopy), dominant, and healthy trees. In both sub-regions, forests were mapped, according to the presence (i.e., recent forest) or absence (i.e., ancient forest) of past land use (former agricultural lands), which has been found to affect soil nutrients (Abadie et al. 2018). Populations were sampled where the past land use was the same, in order to mitigate the impact of soil conditions on trait variation. In the northern part of the study area, for both species, three populations of 30 trees were sampled according to the fire modality (F, "Fire" populations: one fire event in 47 years and NF, "No-fire" populations: no fire event in 47 years). In the South, for $P$. halepensis (PH), 10 populations of 20 trees were sampled, five on burned areas (F, "Fire" populations: two fires events in 59 years) and five on unburned areas (NF, "No-fire" populations: no fire event in 59 years). For P. sylvestris (PS), six populations of 20 trees were sampled, three on burned areas ( 1 fire event in 59 years) and three on unburned areas (no fire event in 59 years) (see Table 1).

\subsection{Fire-related traits measured}

Several traits considered fire-related traits (Pausas 2015a) were measured in the field and in the laboratory (Table 1). We measured several structural traits (on needles and branches) for both species and one functional trait, the serotiny, on P. halepensis only, as $P$. sylvestris does not exhibit this trait as a fire-resister species.

\subsubsection{Structural traits}

All structural traits were selected depending on their role in the different adaptive strategies to fire (resistance or resilience) or on their impact on flammability (e.g., leaf surface to volume ratio, branch bulk density), as traits that enhance or mitigate flammability may vary according to the adaptive strategy (He et al. 2012; Pausas 2015b). We chose to measure the most studied traits in the literature: bark thickness, branch self-pruning, leaf surface to volume ratio, and shoot bulk density.
Bark thickness $(\mathrm{cm})$ is relevant for fire-resistant species because thick bark protects tree tissue from the temperature released during a surface fire. For each tree, four measurements were randomly made around the trunk, $15 \mathrm{~cm}$ above the ground using a ruler, after having drilled the bark $(16 \mathrm{~mm}$ diameter). Measurements were averaged in order to obtain a single data point of bark thickness per tree, taking into account bark fissures (according to the study of Stephens and Libby 2006). Branch self-pruning ( $\mathrm{cm})$, defined as the distance between the ground and the first branch (dead or alive), was also measured with a ruler. This trait allows the resistant species to avoid fuel continuity from the ground to the canopy that could propagate the fire (Fernandes et al. 2008). On the contrary, fire-embracer species favor dead fuel retention to create fuel continuity from the ground to the canopy (Schwilk 2003) allowing the fire to spread in the canopy. Leaf surface-tovolume ratio (SVR, $\mathrm{m}^{-1}$ ) is commonly used in flammability studies (Dimitrakopoulos and Papaioannou 2001; Santoni et al. 2014; Simeoni et al. 2012). SVR increases with fire frequency enhancing flammability for the fire-embracer species. Species presenting high SVR have longer and thinner needles allowing for better fuel ignition and combustion (Parsons et al. 2015; Varner et al. 2015; Zhao et al. 2019). SVR was measured on five needles for each tree; it was based on leaf thickness, length, and elongation (Hachmi et al. 2011) and calculated with the WinSEEDLE program (WinSEEDLETM 2014, (C) Regent Instruments Canada Inc.), using the following formula:

$$
\mathrm{SVR}=(4 / T)\left((1-e / 2)(4 / \pi)^{H}+2 B / \pi W\right)
$$

where $T$ is thickness (m), $W$ is width (m), $e$ is elongation (e $=1 \mathrm{~T} / \mathrm{W})$, and $H$ is a function of the elongation $\left(H=e /(2-e)^{2}\right)$. The last structural fire-related trait we took into account was shoot bulk density $\left(\mathrm{kg} \mathrm{cm}^{-3}\right)$, often used to assess the fuel arrangement, and thus an important factor to assess fuel flammability (Schwilk 2015). Shoot bulk density increases according to fire frequency (Pausas et al. 2012). Width and length were measured on three shoots per tree in order to calculate the volume of the cylinder representing the shoot. Bulk density was then calculated by dividing the weight of the shoot (i.e., needles and twig) by the previously calculated volume.

\subsubsection{Functional trait: serotiny}

Based on the methodology described in Budde et al. (2014), serotiny was assessed during summer when the relative humidity is low as changes in humidity might influence the opening of the cones. For each tree, 20 mature cones or the total number of cones (if the tree had less than 20 cones) were randomly counted on healthy branches using binoculars. The serotiny level was estimated as the number of serotinous cones (closed cones) divided by the total number of cones counted, 
Table 1 Mean \pm standard error for each fire-related trait measured on both species in the different sites sampled in both sub-regions $(n=30$ in the North and $n=20$ in the South). PH, P. halepensis; PS, P. sylvestris; $F$, "Fire" modality; $N F$, "No-Fire" modality

\begin{tabular}{|c|c|c|c|c|c|c|c|}
\hline Species & Geographical location & Site & $\begin{array}{l}\text { Self-pruning } \\
(\mathrm{cm})\end{array}$ & $\begin{array}{l}\text { Bark thickness } \\
(\mathrm{cm})\end{array}$ & $\operatorname{SVR}\left(\mathrm{m}^{-1}\right)$ & $\begin{array}{l}\text { Shoot bulk density } \\
\left(\mathrm{g} \mathrm{cm}^{-3}\right)\end{array}$ & Serotiny $(\%)$ \\
\hline \multirow[t]{16}{*}{ Pinus halepensis } & \multirow[t]{6}{*}{ North } & PHF_1 & $29.10 \pm 14.18$ & $17.95 \pm 5.38$ & $7413.68 \pm 1171.25$ & $4.87 \pm 9.23$ & $15.93 \pm 1.11$ \\
\hline & & PHF_2 & $15.86 \pm 11.81$ & $15.4 \pm 3.38$ & $6360.74 \pm 400.71$ & $3.24 \pm 0.98$ & $7.59 \pm 5.77$ \\
\hline & & PHF_3 & $20.58 \pm 10.51$ & $18.38 \pm 5.55$ & $7033.65 \pm 701.58$ & $2.83 \pm 0.79$ & $3.37 \pm 4.41$ \\
\hline & & PHNF_1 & $17.8 \pm 12.14$ & $15.65 \pm 3.48$ & $6613.22 \pm 375.92$ & $3.28 \pm 1.57$ & $0.67 \pm 2.08$ \\
\hline & & PHNF_2 & $23.61 \pm 12.18$ & $18.11 \pm 4.15$ & $6727.68 \pm 1038.69$ & $3.11 \pm 0.99$ & $0.48 \pm 1.19$ \\
\hline & & PHNF_3 & $7.07 \pm 10.44$ & $19.36 \pm 4.51$ & $6276.65 \pm 274.57$ & $2.27 \pm 0.56$ & $3.27 \pm 5.23$ \\
\hline & \multirow[t]{10}{*}{ South } & PHF_4 & $13.05 \pm 8.13$ & $16.8 \pm 4.69$ & $6665.7 \pm 633.81$ & $3.61 \pm 1.52$ & $19.16 \pm 14.63$ \\
\hline & & PHF_5 & $25.47 \pm 7.9$ & $19.51 \pm 3.3$ & $6821.94 \pm 545.74$ & $2.47 \pm 0.59$ & $3.42 \pm 4.10$ \\
\hline & & PHF_6 & $36.7 \pm 16.09$ & $18.31 \pm 2.87$ & $6628.36 \pm 360.29$ & $3.89 \pm 1.50$ & $3.28 \pm 6.15$ \\
\hline & & PHF_7 & $26.2 \pm 19.62$ & $18.93 \pm 3.96$ & $7543.23 \pm 874.54$ & $3.12 \pm 1.13$ & $0.53 \pm 1.63$ \\
\hline & & PHF_8 & $35.8 \pm 18.95$ & $21.2 \pm 4.74$ & $6797.95 \pm 684.54$ & $5.19 \pm 2.49$ & $1.95 \pm 3.29$ \\
\hline & & PHNF_4 & $41.30 \pm 19.01$ & $21.13 \pm 4.52$ & $6418.45 \pm 633.72$ & $5.12 \pm 1.63$ & $6.32 \pm 8.31$ \\
\hline & & PHNF_5 & $21.98 \pm 10.74$ & $19.44 \pm 3.69$ & $6403.53 \pm 412.5$ & $4.10 \pm 2.51$ & $25.59 \pm 28.17$ \\
\hline & & PHNF_6 & $18.80 \pm 16.02$ & $19.15 \pm 5.01$ & $6000.84 \pm 390.19$ & $6.98 \pm 3.80$ & $17.00 \pm 16.65$ \\
\hline & & PHNF_7 & $40.70 \pm 18.81$ & $22.95 \pm 3.89$ & $7234.52 \pm 646.56$ & $5.35 \pm 1.76$ & $1.08 \pm 2.77$ \\
\hline & & PHNF_8 & $34.27 \pm 20.45$ & $19.49 \pm 4.75$ & $7267.76 \pm 713.88$ & $4.51 \pm 1.55$ & $4.31 \pm 6.48$ \\
\hline \multirow[t]{12}{*}{ Pinus sylvestris } & \multirow[t]{6}{*}{ North } & PSF_1 & $13.17 \pm 4.65$ & $9.33 \pm 2.49$ & $5140.6 \pm 348.45$ & $4.16 \pm 0.94$ & - \\
\hline & & PSF_2 & $14.83 \pm 6.28$ & $6.43 \pm 2.34$ & $5084.32 \pm 517.66$ & $6.49 \pm 1.81$ & - \\
\hline & & PSF_3 & $17.54 \pm 12.68$ & $9.79 \pm 3.21$ & $4907.01 \pm 427.87$ & $5.79 \pm 1.47$ & - \\
\hline & & PSNF_1 & $16.33 \pm 6.11$ & $10.68 \pm 2.75$ & $5107.01 \pm 453.22$ & $5.74 \pm 1.99$ & - \\
\hline & & PSNF_2 & $13.83 \pm 7.94$ & $9.08 \pm 2.81$ & $5185.84 \pm 480.49$ & $4.68 \pm 1.40$ & - \\
\hline & & PSNF_3 & $15.2 \pm 6.67$ & $10.47 \pm 3.84$ & $4656.25 \pm 516.42$ & $4.62 \pm 1.10$ & - \\
\hline & \multirow[t]{6}{*}{ South } & PSF_4 & $54.2 \pm 38.55$ & $11.7 \pm 4.25$ & $5169.69 \pm 545.77$ & $11.46 \pm 5.79$ & - \\
\hline & & PSF_5 & $18.3 \pm 8.5$ & $6.63 \pm 3.6$ & $5344.53 \pm 491.44$ & $13.8 \pm 4.48$ & - \\
\hline & & PSF_6 & $19.6 \pm 17.01$ & $10.9 \pm 4.14$ & $5661.98 \pm 509.23$ & $12.16 \pm 4.64$ & - \\
\hline & & PSNF_4 & $20.23 \pm 5.49$ & $12.13 \pm 10.26$ & $4909.1 \pm 599.18$ & $12.91 \pm 5.53$ & - \\
\hline & & PSNF_5 & $8.85 \pm 10.77$ & $13.75 \pm 4.30$ & $5511.53 \pm 715.05$ & $8.72 \pm 2.43$ & - \\
\hline & & PSNF_6 & $20.05 \pm 37.55$ & $12.55 \pm 3.92$ & $5659.93 \pm 449.5$ & $12.30 \pm 5.91$ & - \\
\hline
\end{tabular}

multiplied by 100 (in percentage). A cone was assumed to be serotinous if it was older than 3 years (mature) and well formed in order to avoid including dead cones infested by parasites (that remained closed but were not serotinous). The age of the cone was determined using visual observations, counting only gray cones indicating that they are mature (Hernández-Serrano et al. 2014).

\subsubsection{Environmental and tree cofactors}

As mentioned above, traits considered to be related to fire can vary according to many environmental factors (e.g., elevation, slope, soil characteristics) or trees' characteristics (e.g., diameter at breast height) which must be taken into account in the analyses as cofactors. In addition, we used tree age as a proxy of ontogeny and as cofactor because some traits considered fire related, such as bark thickness, could vary at different ontogenetic stages (Schwilk and Ackerly 2001; Martin-Sanz et al. 2019).
For each tree sampled, the plant height (from ground to apex, in m) was measured using a Vertex Laser VL5. In addition, the trunk diameter at breast height (DBH, in $\mathrm{cm}$ ) was measured at $1.30 \mathrm{~m}$, using a diameter tape stick, on the uphill side of the tree due to the slope. These two cofactors are sensitive to soil nutrient and inter-individual competition (Fang et al. 2005; Leech 1984; Niinemets and Kull 1995), and tree height can also be considered a good proxy for ontogeny due to the rules of plant allometry (Day and Greenwood 2011). For each tree, in order to estimate the tree age and the relative growth rate (RGR, \%), one core was collected on the trunk at $1.30 \mathrm{~m}$ (breast height) using a Pressler increment borer. After collection, the cores were glued on a corrugated cardboard before being sanded, cleaned, and scanned with a high-resolution scanner at $1200 \mathrm{dpi}$. Using WinDENDRO program (WinDENDROTM 2014, (C) Regent Instruments Canada Inc.), we counted the rings from the center to the 
bark to assess the tree age and calculated RGR as follows (South 1995):

Relative growth rate $=\frac{\text { Growth } \text { of the last five years }}{\text { Total growth }} \times 100$

The growth of the last 5 years is the sum of the width of the last five rings of the core, and the total growth is the sum of all the ring widths in the core. We included RGR as cofactor in our analyses because this trait is integrative to many environmental conditions of the site such as competition or water and nutrient supply, reflecting survival and fecundity. It is therefore a good indicator of the tree fitness (Bolnick et al. 2011; Helluy et al. 2020). In addition, we assessed the population basal area per hectare using an angle gauge in five different locations in each population given that this parameter can be considered a competition index (Schröder and Gadow 1999).

Each site was georeferenced using a GPS giving the elevation (m) and the latitude (degree); we also measured the slope (\%) using the Vertex Laser VL5. Finally, using MeteoFrance database (www.meteofrance.fr), temperature and precipitation recorded in each site were averaged over the last 10-year period (i.e., from 2009 to 2019), from the nearest weather station to each site. As sites could be close to each other, a given weather station could be the same for several sites. Finally, we also chose to consider the site by itself as a cofactor, as trait variation could also be related to other site-specific factors.

\subsection{Data analyses}

Preliminary analyses were performed in order to select traits for further analyses (principal component analyses performed on both species and location datasets in order to select significant traits for further analyses). In these preliminary analyses (see Fig. 3 and Fig. 4 in annex), all of the traits measured were displayed on the three first components that explained more than $60 \%$ of the total variance and with eigenvalues higher than 1. Moreover, no segregation was observed between "Fire" and "No-Fire" populations.

For both species, analyses were carried out for the entire study area as well as for both sub-regions, as they differed in terms of environmental conditions. We chose to perform a one-way ANOVA followed by a Student's $t$ test for each species, in order to highlight possible differences in trait data according to the fire modality alone. Due to the possible strong influence of other factors on trait variation, we then performed linear mixed-effect models in the R package lme4 (Bates et al. 2018) for each fire-related trait. This analysis allowed us to take into account all of the environmental and tree characteristics measured while including sampling site as a random effect. The best model was selected using a stepwise approach based on the Akaike Information Criterion (AIC) (dredge function of MuMIn R package; Barton and Barton 2019). We extracted the residuals of the selected model for each trait in order to control for cofactor effects and to be able to test the effect of the fire modality without any other interaction (Kruskal-Wallis test as residuals did not follow a normal distribution). Finally, we also performed the Levene test on the residuals, assessing the equality of variance (i.e., data dispersion) for each trait according to the fire modality. Even if this dispersion cannot be quantified, the results indicate the response to fire perturbation (Mitchell and Bakker 2014).

\section{Results}

\subsection{Variation of $P$. halepensis' fire-related traits ac- cording to the fire modality}

Regardless of the trait and the geographical location, the differences obtained between both fire modalities (one-way ANOVA) showed unclear results, often non-significant (see Table 5 in annex). As this could be due to a possible effect of other factors on the traits, they were taken into account as cofactors in the following analyses.

Regarding the results obtained for the entire geographical area, three environmental cofactors were regularly selected as significantly affecting the traits: age, elevation, and latitude (Table 2). For instance, serotiny level was explained by several cofactors including latitude and weather characteristics (i.e., precipitation and temperature) but also tree age and height. Tree height also affected shoot bulk density and slope only explained the variation of SVR. Regardless of the trait, even when these characteristics were controlled working with the residuals of the best models obtained, there were still no significant differences between fire modalities; the same results were obtained testing the trait variance highlighting the overriding effect of the environmental and tree characteristics.

Regarding the northern part of the study area, elevation affected all of plant traits except SVR which was not explained by any cofactor. Bark thickness was also affected by tree age and site slope, and shoot bulk density by basal area and tree height. Most cofactors (i.e., basal area, elevation, tree height, RGR, and slope) affected serotiny making this trait one the most environment-dependent. As for the entire study area, even when these characteristics were controlled, there were still no significant differences between fire modalities, regardless of the trait. In contrast, Levene tests revealed significant differences in the variance of self-pruning and serotiny level between the fire modalities. We noticed a greater range of data for "No-fire" populations compared to "Fire" populations regarding self-pruning, contrary to the pattern highlighted for serotiny level (greater range for "Fire" populations).

Regarding the southern part of the study area, self-pruning and bark thickness were only affected by tree age while 
precipitation as well as basal area had an effect on shoot bulk density and SVR. This latter trait was also affected by temperature, latitude, and slope. Serotiny level was explained by all of the cofactors except RGR. There were still no significant differences between fire modalities regardless of the trait when these characteristics were controlled. However, the variance of serotiny level significantly differed between "Fire" and "non-fire" populations, with a greater range in "No-fire" populations.

\subsection{Variation of $P$. sylvestris' fire-related traits ac- cording to the fire modality}

As for P. halepensis, one-way ANOVA testing difference both fire modalities for $P$. sylvestris showed unclear results, often non-significant (see Table 5 in annex). As this could be due to a possible effect of other factors on the traits, we used them as cofactors in the following analyses.

Regarding the effect of cofactors on the fire-related traits in the entire study area, we found that bark thickness was influenced by tree height as well as by site temperature, SVR and shoot bulk density by tree height and elevation but also by precipitation for the former and by latitude for the latter (Table 2). Regarding the northern region, P. sylvestris' traits were either affected by tree height (bark thickness and SVR) or elevation (self-pruning and shoot bulk density) while in the southern region, tree height and elevation were relevant cofactors explaining trait variation and self-pruning was also affected by slope and basal area.

Even controlling these characteristics, the results of tests on either trait medians or variances were not significant according to the fire modality and regardless of their geographical location.

\section{Discussion}

\subsection{Effect of recent fire activity on fire-related traits}

The aim of the present study was to determine whether different populations of the same species could display differences in their fire-related traits according to their recent fire history. For both $P$. halepensis and $P$. sylvestris, the trait variation observed between fire modalities was inconclusively related to the adaptive strategies of the species or non-significant The lack of a clear pattern between fire modalities could be due to insufficient differences in fire recurrence between both modalities as we took into account only the recent fire history (as fire data before the 1970s for the North and before 1960s for the South have not been recorded). Even if the studied traits increase plant fitness in case of fire, more generations of trees submitted to several fire events could be needed to highlight intraspecific differences in their fire-related traits. In fact, the
"Fire" populations we studied have undergone at most two fires in the last 50-60 years. As fire frequency is expected to increase with climate change, it will therefore be important to understand how fire-related traits will vary in response to higher fire frequency.

Most fire-related traits that developed in different fireadaptive strategies have taken thousands of years to evolve in the genome of plants that were subjected to fire, increasing biodiversity in fire-prone ecosystems (Keeley et al. 2011; Ne'eman et al. 2012). However, even if these processes took a long time, some highly heritable traits, such as serotiny level in fire-embracer species, can vary in response to a slight increase in the fire frequency (Budde et al. 2014, 2017). Indeed, serotiny is known for its high phenotypic variability among species, populations, and geographical areas, though this variability could not be solely due to fire (Tapias et al. 2004; Voltas et al. 2008; He et al. 2012; Ne'eman et al. 2012). In fact, serotiny levels can be affected by many environmental factors as those highlighted in our results, but also such as extreme drought or pest attack (Nathan et al. 1999; González-Ochoa and de Heras 2002; Ne'eman et al. 2004; Martín-Sanz et al. 2017). The reason why the results on the comparison of traits between fire modalities are not clear may also be due to the fact that environmental and tree characteristics outweigh the effect of fire modality.

Though even by controlling for the effect of environmental and tree characteristics and ontogeny (i.e., tree age and height), the effect of the fire modality on traits was still not significant. However, we found a significant difference between the variances of serotiny level and self-pruning (in the North only) regarding $P$. halepensis according to the fire modality highlighted by a variation of the dispersion of data. Fire frequency could act as a driving factor for these two traits, even if there is no actual significant difference in their mean or median values according to the fire modality. The fact that serotiny level, like self-pruning, had a different distribution according to the recent fire activity could also indicate that these traits are controlled by a simple genetic mechanism (Lamont et al. 2020). Fire acts as a disturbance, increasing phenotypic plasticity (Keeley and Pausas 2019), which is the ability to express different phenotypes from the same genotype according to different environmental conditions (Bradshaw 1965; Martín-Sanz et al. 2017). In some cases, phenotypic plasticity may be adaptive (Drenovsky et al. 2012; Richards et al. 2006) and improves the evolution of novel beneficial gene activity (Espinosa-Soto et al. 2011). Phenotypic plasticity could thus be adaptive for some key fire-related traits of the species' adaptive strategy to fire in order to favor genomes that would be better adapted to their new environment (Chevin and Hoffmann 2017; Schmid and Guillaume 2017). However, little is known about the genetic basis of phenotypic diversity and its adaptive part (VizcaínoPalomar et al. 2020). In the northern part of the study area, the 


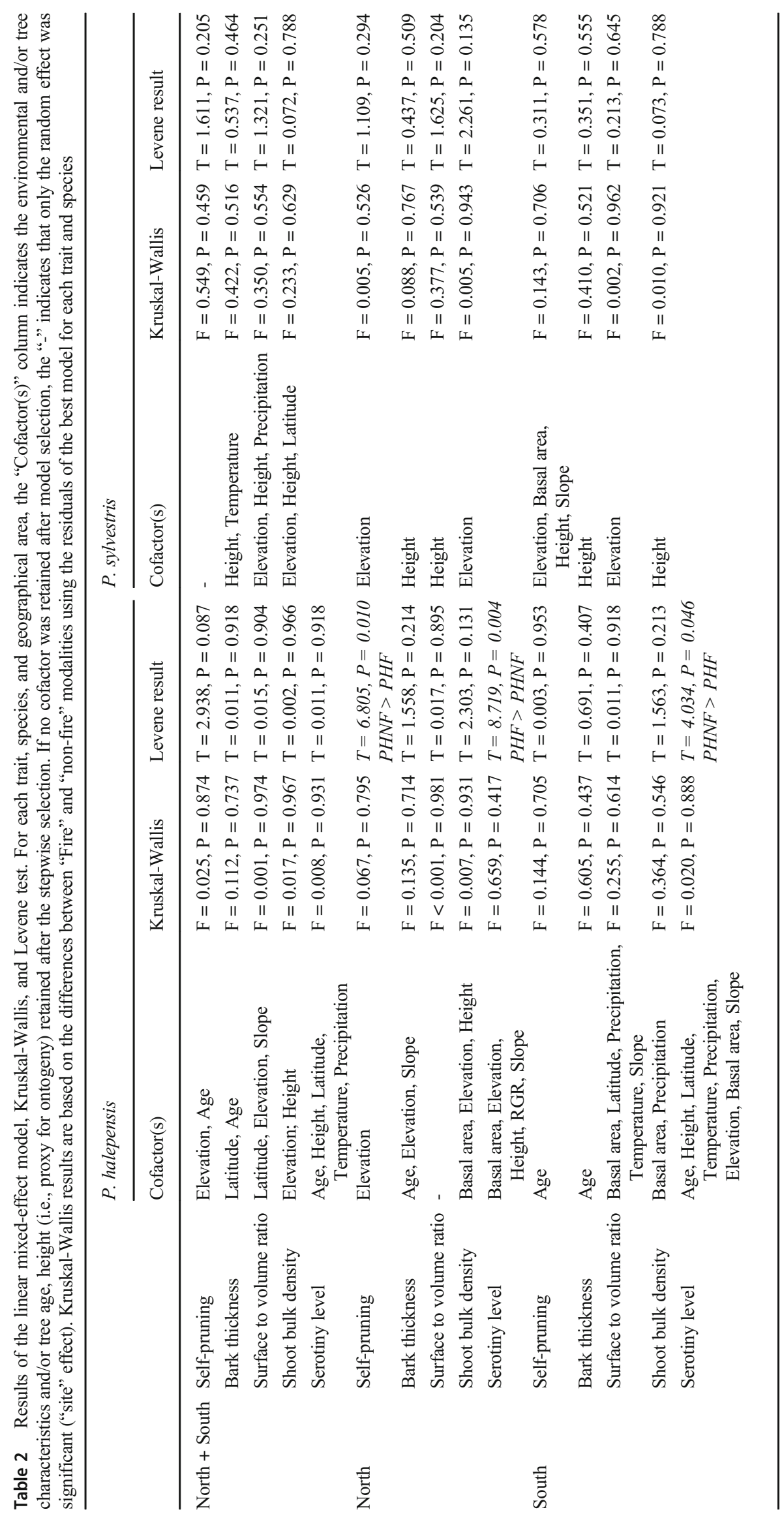

INRAC 包 springer 
variance of serotiny level considered functional diversity was higher for populations that had undergone at least one fire during the last 47 years while it was the contrary in the South (higher for "No-fire" populations). Northern Provence is hardly impacted by fires, and "Fire" populations in this area could have been less affected by previous fire events compared to the fire-prone southern Provence. When a new disturbance affects an ecosystem, the phenotypic diversity will increase (i.e., greater range) to improve the adaptive capacity of individuals (Espinosa-Soto et al. 2011; Sahoo et al. 2020), as it was the case for the serotiny level in the northern part of the study area. In contrast, in the South, the lower variance of serotiny level in the "No-fire" populations can testify that recurrent fires could act as bottleneck selective pressure (Budde et al. 2017; Suárez et al. 2012).

\subsection{Effect of recent fire activity on traits taking cofactors into account}

In contrast to the fire modality, we found that environmental (e.g., elevation, slope), tree characteristics (e.g., $\mathrm{DBH}$ ), and ontogeny (using tree age and height as proxy) played a significant role in the explanation of trait variation. The role of these characteristics is a well-studied topic; in the current study, the purpose was to consider them as cofactors in the analyses to avoid confounding results with the effect of fire modality on traits. Indeed, previous studies have shown, for example, that water and nutrient availability in the soil could have an effect on leaf thickness and surface area (Cunningham et al. 1999; Ordoñez et al. 2009) which could be difficult to disentangle from that of fire. Ecological advantages of fire-related traits such as self-pruning or bark thickness are numerous, e.g., to allocate energy only to branches exposed to sunlight or to act as a physical barrier against cold (Rosell 2016). Nevertheless, these traits are also considered firerelated because they mitigate the impact of fire in resistant species (Fernandes et al. 2008; Keeley et al. 2011; Pausas 2015b). Regarding bark thickness, a recent study of Martin-Sanz et al. (2019) highlighted that P. halepensis' basal bark thickness in common garden was virtually invariant among populations and that breast-height bark thickness measurement was more discriminant. They showed that this trait strongly depends on water availability (i.e., water-stressed trees have thinner and so higher risk to die in case of fire) regarding populations in common garden underlying the importance of trait measurement and identify the source of phenotypic variation. However, this is yet to be confirmed in natural populations where cofactors can act synergistically. The fact that the variation of some traits depends on several factors (fire and environmental/tree characteristics, ontogeny) makes it difficult to determine which factor overrides the other in natural populations. These "typical" traits can be considered true adaptations to fire, but with an increasing evidence supporting the role of other environmental factors in their phenotypic expression (i.e., plasticity; Keeley et al. 2011; Lamont and He 2017). Including "site" as a random effect as well as several environmental/tree cofactors in our analyses, we acknowledged that the traits we studied could also be influenced by other factors aside from fire regarding intraspecific differences. The fact that the analyses testing for the effect of fire modality on traits were often non-significant, even when the environmental and tree characteristics were controlled, except for some key traits (e.g., serotiny, self-pruning), is another proof of their overriding effect over recent fire activity.

\section{Conclusion}

We showed that the fire-related traits studied did not vary in relation to the recent fire history of both pine species, even when the effects of environmental and plant characteristics were controlled in the analyses. However, the variance of some key traits (e.g., self-pruning and serotiny level) of the fire-embracer $P$. halepensis' adaptive strategy significantly varied between "Fire" and "No-fire" modalities. These results showed that not all species are able to respond quickly to fire disturbance in adapting their traits accordingly. Only the traits most related to fire present higher variance according to recent fire activity. In order to better highlight phenotypic variability caused by the fire frequency, future sampling should take into account more contrasted fire modalities (i.e., recurrence of four to six fires for the "Fire" populations vs 0 fire over a longer period than the one studied), as was done in Budde et al. (2014). Investigating differences in gene expression for the most heritable traits such as serotiny, for instance studying genetic variation in these quantitative traits (Josephs et al. 2017), could also be another way to highlight adaptations to fire. Indeed, genetic tools, such as Genome-Wide Association Study (GWAS), are becoming more and more powerful, allowing Budde et al. (2014), for instance, to determine that $29 \%$ of the total variation in the serotiny level for Spanish $P$. pinaster natural populations was explained by only 17 genetic markers (Single Nucleotid Part). Eventually, these types of analyses will help to better anticipate forest ecosystem responses (i.e., acclimation, adaptation, or mortality) to global change in the near future and to identify adaptable genotype in the framework of the climate change. In our study, traits have been measured on trees that are the result of the regeneration of trees killed by fire (i.e., stand replacing fires). For further work, it could be also interesting to study acclimation, especially for resistant species, measuring fire- 
related trait variation before and after fire events on trees that have survived.

Acknowledgments The authors would like to thank Roland Esteve, JeanMichel Lopez, and Mathieu Audouard for their help in sample collection, Maxime Cailleret and Maxime Logez for their suggestions concerning the data analyses, and also Kurt Villsen for the English revision.

Funding This work has been funded by the FEDER-POIA European Program "Vulter-Baronnies" \# PA0005333.

Data availability The datasets generated during and/or analyzed during the current study are available in the Zenodo repository, https://doi.org/ 10.5281/zenodo.4117707.

\section{Compliance with ethical standards}

Conflict of interest The authors declare that they have no conflict of interest.

Ethics approval The authors declare that they obtained the approval of the National Forest Office (ONF - Drôme-Ardèche) and of the Natural Regional Park ethics committee for conducting the study in 'Baronnies Provençales Natural Regional Park'.

\section{Annexes}

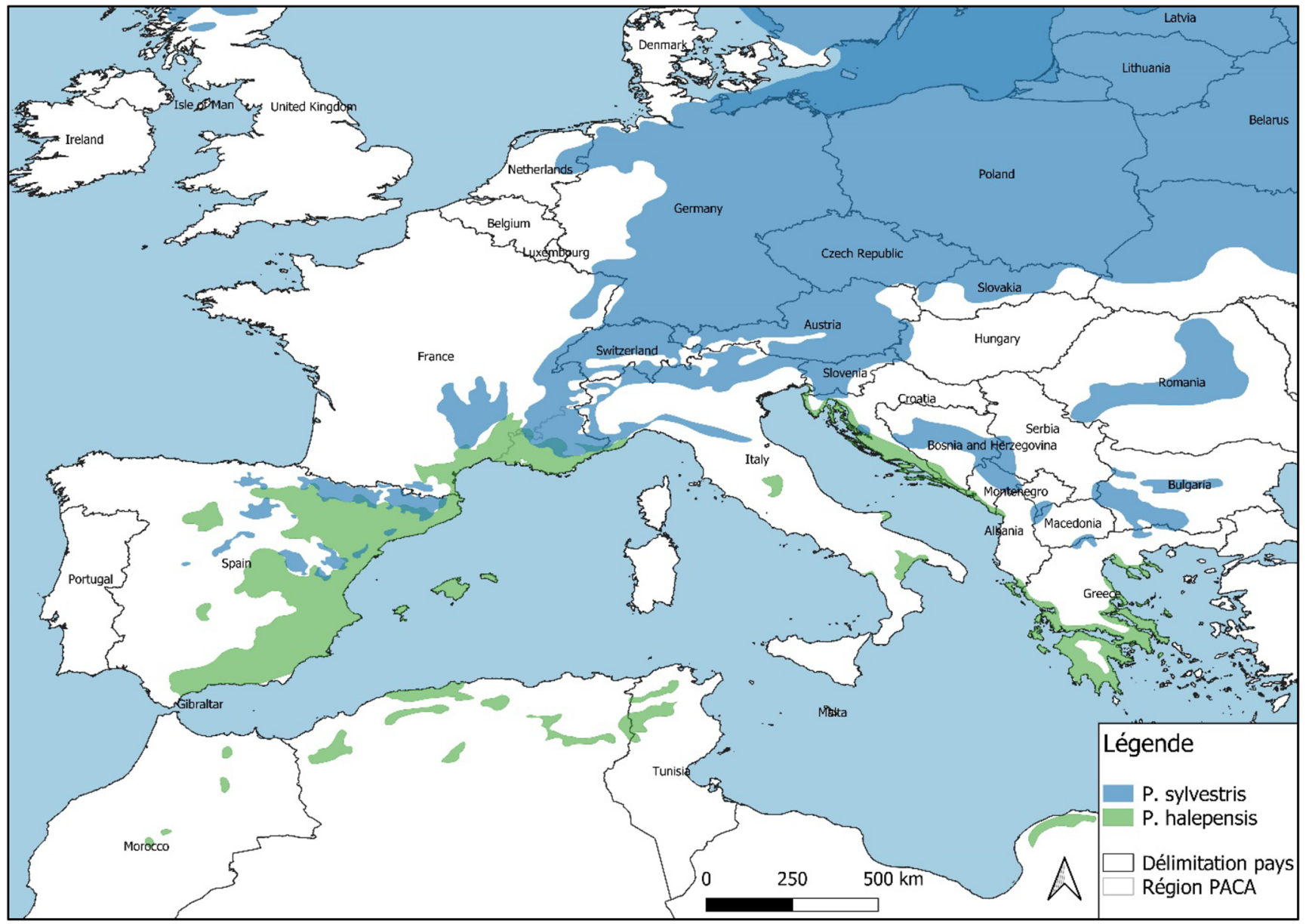

Fig. 2 Map of Pinus halepensis' and Pinus sylvestris' distribution in the Mediterranean basin 


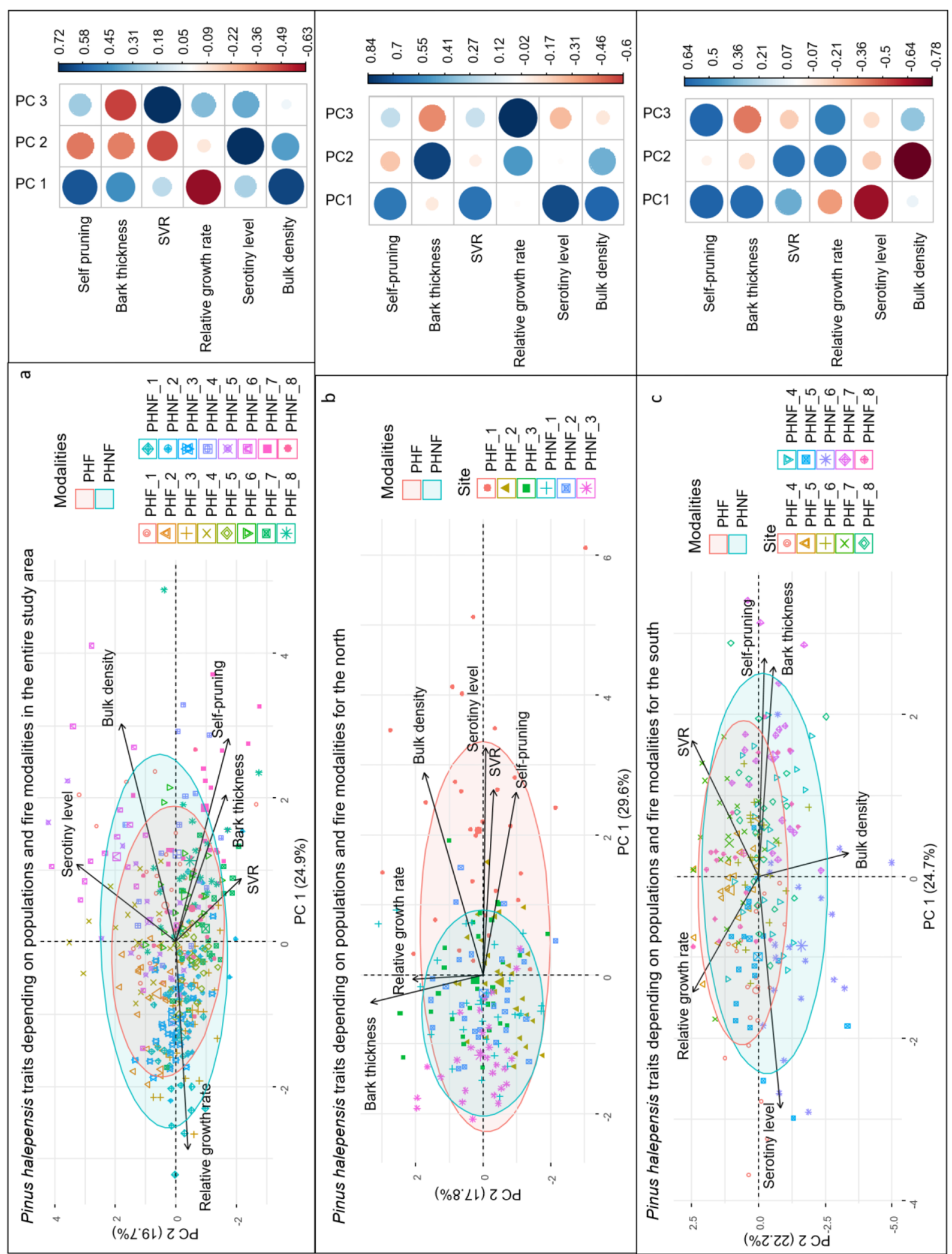

Fig. 3 Biplots of principal component analyses (only the two first components are shown) illustrating relationships between fire-related traits (SVR, surface to volume ratio) and fire recurrence modalities in the entire study area (a), the northern part (b), and the southern part (c) for $P$. halepensis. Populations sampled in the high fire recurrence modality (PHF) are circled in blue and populations sampled in the no fire modality (PHNF) are circled in orange. The correlation plots indicate the regression coefficient of each trait on each component; the darker and larger the circle color and size, the stronger the correlation 


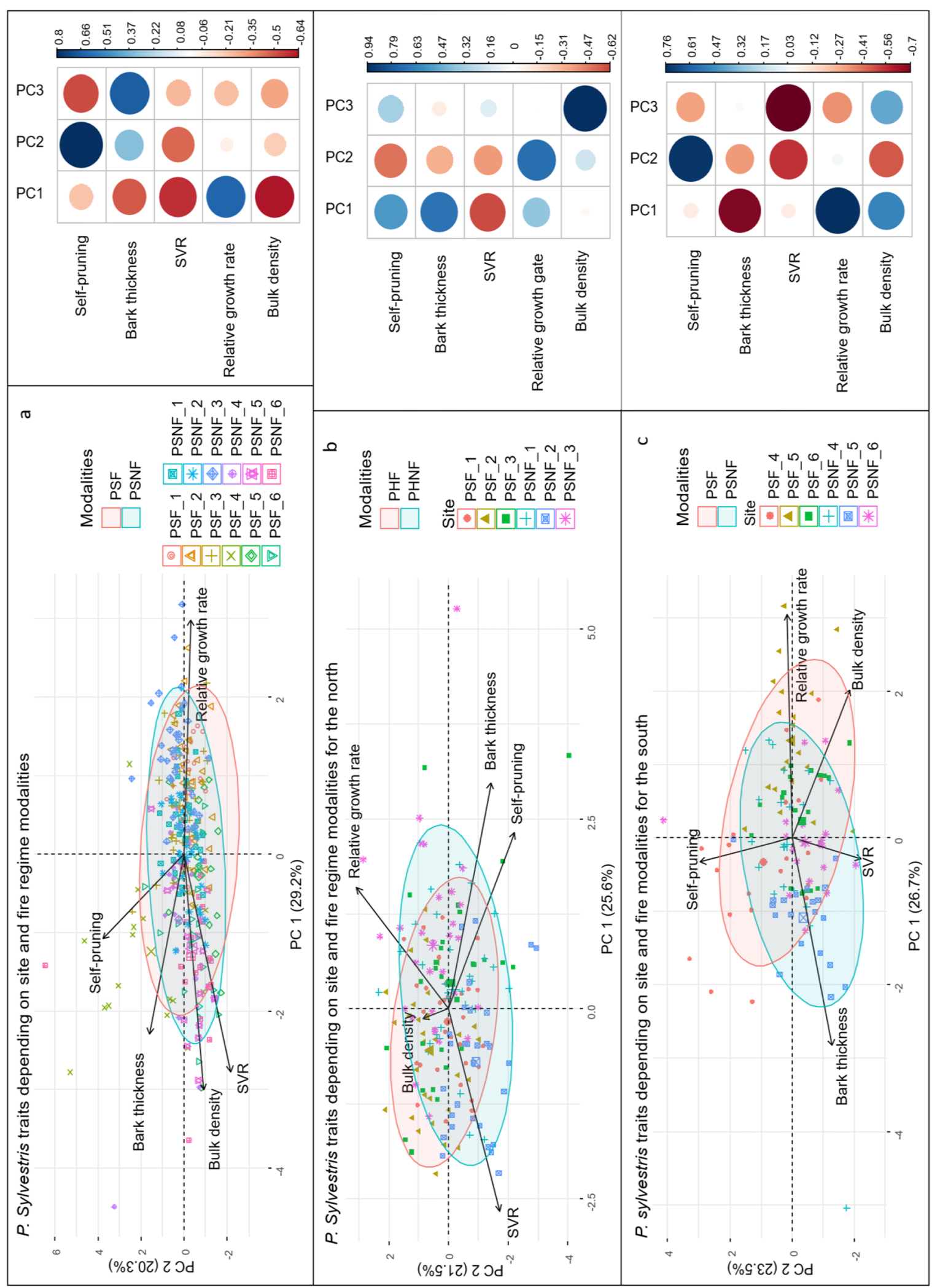

Fig. 4 Biplots of principal component analyses (only the two first components are shown) illustrating relationships between fire-related traits (SVR, surface to volume ratio) and fire recurrence modalities in the entire study area (a), the northern part (b), and the southern part (c) for $P$. sylvestris. Populations sampled in the high fire recurrence modality
(PHF) are circled in blue and populations sampled in the no fire modality (PHNF) are circled in orange. The correlation plots indicate the regression coefficient of each trait on each component; the darker and larger the circle color and size, the stronger the correlation 


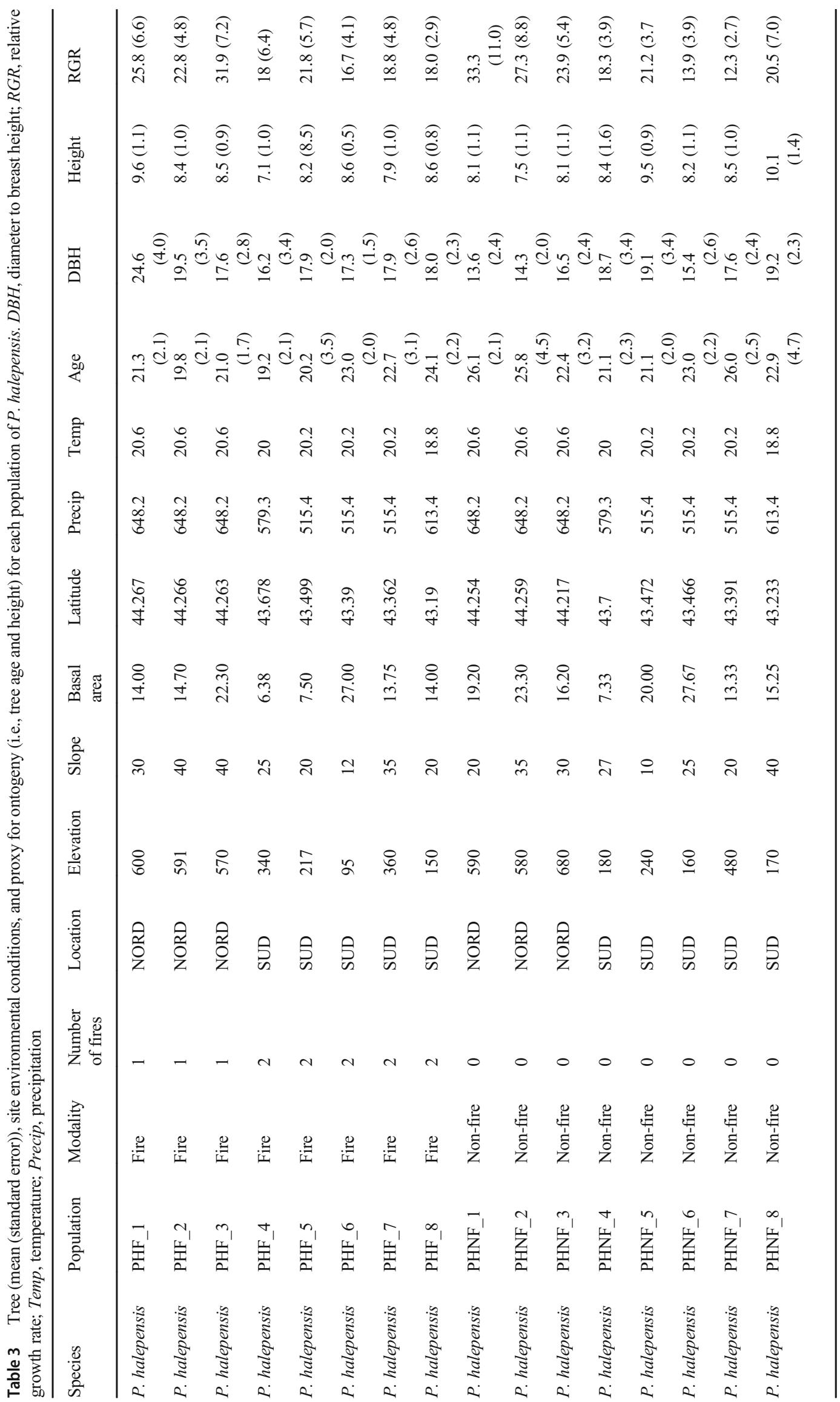




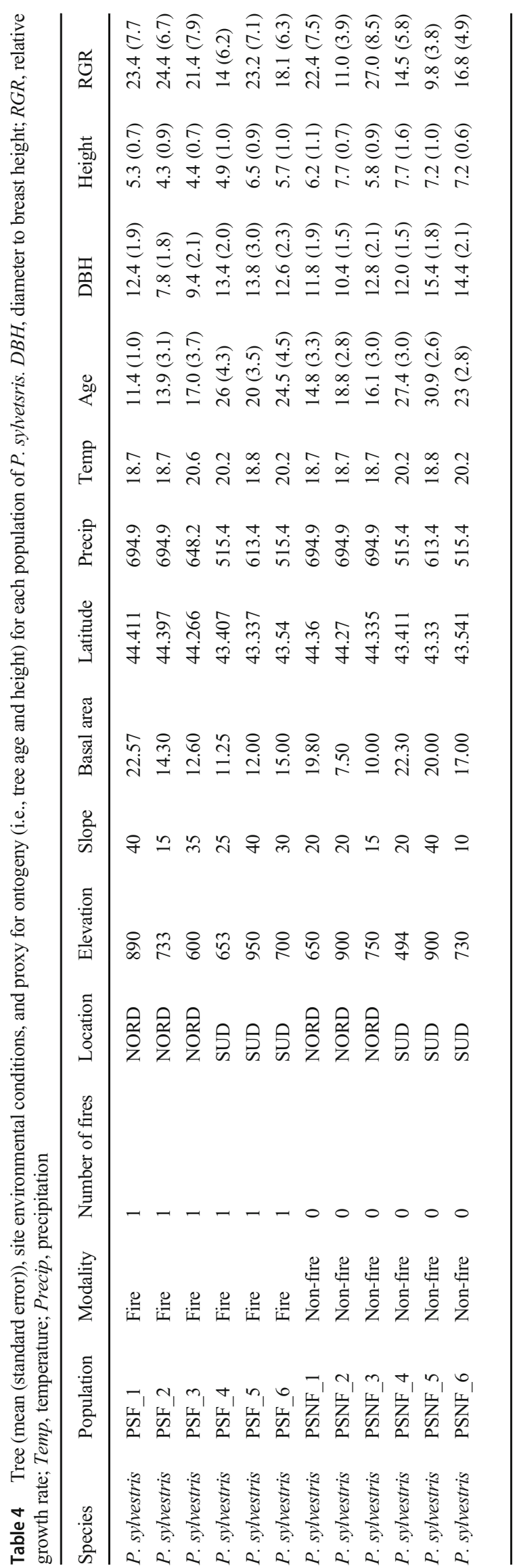


Table 5 Results of one-way ANOVA (F, Fisher test; P, probability) performed on the traits sampled, for each species, in the different geographical locations and testing the differences between the two fire modalities. In italics: log transformed data; in bold: significant results. $P H F$, $P$. halepensis in "Fire" modality; $P H N F$, P. halepensis in "NonFire" modality; $P S F, P$. sylvestris in "Fire" modality; $P S N F$, $P$. sylvestris in "Non-Fire" modality

\begin{tabular}{|c|c|c|c|}
\hline & & P. halepensis & P. sylvestris \\
\hline \multirow[t]{6}{*}{ North+ South } & Self-pruning & $F=0.66, P=0.42$ & $F=5.73, P=0.017$ \\
\hline & Bark thickness & $F=2.57, P=0.11$ & $F=24.33, P<0.01$ \\
\hline & & & $P S F<P S N F$ \\
\hline & Surface to volume ratio & $F=16.70, P<0.01$ & $\mathrm{~F}=0.65, \mathrm{P}=0.42$ \\
\hline & Relative growth rate & $\begin{array}{l}\mathbf{P H F}>\mathbf{P H N F} \\
\mathrm{F}=0.07, \mathrm{P}=0.79\end{array}$ & $\begin{array}{l}\mathrm{F}=13.85, \mathrm{P}<0.01 \\
\mathrm{PSF}>\mathrm{PSNF}\end{array}$ \\
\hline & Bulk density & $F=1.67, P=0.20$ & $F=2.59, P=0.11$ \\
\hline \multirow[t]{5}{*}{ North } & Self-pruning & $F=3.91, P=0.05$ & $F=0.00, P=0.94$ \\
\hline & Bark thickness & $\begin{array}{l}\boldsymbol{P H F}>\boldsymbol{P H N F} \\
F=0.80, P=0.37\end{array}$ & $\begin{array}{l}\mathrm{F}=11.44, \mathrm{P}<0.01 \\
\mathrm{PSF}<\mathrm{PSNF}\end{array}$ \\
\hline & Surface to volume ratio & $F=10.76, P<0.01$ & $\mathrm{~F}=0.80, \mathrm{P}=0.37$ \\
\hline & Relative growth rate & $\begin{array}{l}\text { PHF }>\text { PHNF } \\
F=0.81, P=0.37\end{array}$ & $\begin{array}{l}\mathrm{F}=5.15, \mathrm{P}=0.02 \\
\mathrm{PSF}>\mathrm{PSNF}\end{array}$ \\
\hline & Bulk density & $F=12.61, P<0.01$ & $F=3.09, P=0.08$ \\
\hline \multirow[t]{7}{*}{ South } & Self-pruning & $\begin{array}{l}\boldsymbol{P H F}>\boldsymbol{P H N F} \\
F=1.05, P=0.31\end{array}$ & $\begin{array}{l}F=8.64, P<0.01 \\
P S F>P S N F\end{array}$ \\
\hline & Bark thickness & $F=5.62, P=0.02$ & $F=8.56, P<0.01$ \\
\hline & & $P H F<P H N F$ & PSF $<$ PSNF \\
\hline & Surface to volume ratio & $F=4.62, P=0.03$ & $\mathrm{~F}=0.08, \mathrm{P}=0.78$ \\
\hline & Relative growth rate & $\begin{array}{l}\text { PHF }>\text { PHNF } \\
F=2.85, P=0.09\end{array}$ & $\begin{array}{l}\mathrm{F}=15.05, \mathrm{P}<0.01 \\
\mathrm{PSF}>\mathrm{PSNF}\end{array}$ \\
\hline & Bulk density & $F=22.79, P<0.01$ & $\mathrm{~F}=1.55, \mathrm{P}=0.22$ \\
\hline & & $P H F<P H N F$ & \\
\hline
\end{tabular}

\section{References}

Abadie J, Dupouey J-L, Avon C, Rochel X, Tatoni T, Bergès L (2018) Forest recovery since 1860 in a Mediterranean region: drivers and implications for land use and land cover spatial distribution. Landscape Ecol 33:289-305. https://doi.org/10.1007/s10980-0170601-0

Angelstam P, Kuuluvainen T (2004) Boreal forest disturbance regimes, successional dynamics and landscape structures: a European perspective. Ecol Bull:117-136

Barton K, Barton MK (2019) Package 'MuMIn'. R package version 1

Bates D, Maechler M, Bolker B, Walker S, Christensen RHB, Singmann H, Dai B, Scheipl F, Grothendieck G, Green P (2018) Package 'Ime4'. Version 1:17

Bede-Fazekas Á, Horváth L, Kocsis M (2014) Impact of climate change on the potential distribution of Mediterranean pines. Időjárás 118: $41-52$

Bolnick DI, Amarasekare P, Araújo MS, Bürger R, Levine JM, Novak M, Rudolf VH, Schreiber SJ, Urban MC, Vasseur DA (2011) Why intraspecific trait variation matters in community ecology. Trends Ecol Evol 26:183-192. https://doi.org/10.1016/j.tree.2011.01.009

Bond WJ, Keeley JE (2005) Fire as a global 'herbivore': the ecology and evolution of flammable ecosystems. Trends Ecol Evol 20:387-394. https://doi.org/10.1016/j.tree.2005.04.025
Bond WJ, Midgley JJ (1995) Kill thy neighbour: an individualistic argument for the evolution of flammability. Oikos 73:79-85

Bond WJ, van Wilgen BW (1996) Fire and plants. Population and Community Biology Series 14

Bradshaw AD (1965) Evolutionary significance of phenotypic plasticity in plants. Adv Genet 13:115-155

Brumelis G, Elferts D, Liepina L, Luce I, Tabors G, Tjarve D (2005) Age and spatial structure of natural Pinus sylvestris stands in Latvia. Scand J Forest Res 20:471-480. https://doi.org/10.1080/ 02827580500339526

Budde KB, Heuertz M, Hernández-Serrano A, Pausas JG, Vendramin GG, Verdú M, González-Martínez SC (2014) In situ genetic association for serotiny, a fire-related trait, in Mediterranean maritime pine (Pinus pinaster). New Phyto 201:230-241. https://doi.org/10. 1111/nph.12483

Budde KB, González-Martínez SC, Navascués M, Burgarella C, Mosca E, Lorenzo Z, Zabal-Aguirre M, Vendramin GG, Verdú M, Pausas JG (2017) Increased fire frequency promotes stronger spatial genetic structure and natural selection at regional and local scales in Pinus halepensis Mill. Ann Bot-London 119:1061-1072. https://doi.org/ 10.1093/aob/mcw286

Castellanos MC, González-Martínez SC, Pausas JG (2015) Field heritability of a plant adaptation to fire in heterogeneous landscapes. Mol Ecol 24(22):5633-5642 
Causley CL, Fowler WM, Lamont BB, He T (2016) Fitness benefits of serotiny in fire-and drought-prone environments. Plant Ecol 217: 773-779. https://doi.org/10.1007/s11258-015-0552-y

Chevin L-M, Hoffmann AA (2017) Evolution of phenotypic plasticity in extreme environments. Philosophical Transactions of the Royal Society B: Biological Sciences 372:20160138. https://doi.org/10. 1098/rstb.2016.0138

Climent J, Tapias R, Pardos JA, Gil L (2004) Fire adaptations in the Canary Islands pine (Pinus canariensis). Plant Ecol 171:185-196

Cruz O, Garcia-Duro J, Casal M, Reyes O (2019) Role of serotiny on Pinus pinaster Aiton germination and its relation to mother plant age and fire severity. iForest-Biogeosciences and. Forestry 12:491

Cunningham SA, Summerhayes B, Westoby M (1999) Evolutionary divergences in leaf structure and chemistry, comparing rainfall and soil nutrient gradients. Ecol Monogr 69:569-588. https://doi.org/ 10.1890/0012-9615

Day ME, Greenwood MS (2011) Regulation of ontogeny in temperate conifers. Size-and age-related changes in tree structure and function. Springer, Berlin, pp 91-119. https://doi.org/10.1007/978-94-0071242-3_4

Dimitrakopoulos A, Papaioannou KK (2001) Flammability assessment of Mediterranean forest fuels. Fire Technol 37:143-152

Drenovsky RE, Khasanova A, James JJ (2012) Trait convergence and plasticity among native and invasive species in resource-poor environments. Am J Bot 99:629-639. https://doi.org/10.3732/ajb. 1100417

Dupire S, Curt T, Bigot S, Fréjaville T (2019) Vulnerability of forest ecosystems to fire in the French Alps. Eur J For Res 138(5):813-830

Emberger L (1963) Bioclimatic map of the Mediterranean zone: explanatory notes, UNESCO-FAO

Espelta JM, Arnan X, Rodrigo A (2011) Non-fire induced seed release in a weakly serotinous pine: climatic factors, maintenance costs or both? Oikos 120:1752-1760

Espinosa-Soto C, Martin OC, Wagner A (2011) Phenotypic plasticity can facilitate adaptive evolution in gene regulatory circuits. BMC Evol Biol 11:5

Fang Y, Mo J, Zhou G, Xue J (2005) Response of diameter at breast height increment to $\mathrm{N}$ additions in forests of Dinghushan biosphere reserve. J Trop Sub Bot 13:198-204

Fargeon H, Dupuy J-L, Martin-Stpaul N, Pimont F (2017) Climate change impact on wildfires: where do the greatest uncertainties lie?

Fernandes PM, Vega JA, Jimenez E, Rigolot E (2008) Fire resistance of European pines. Forest Ecol Manag 256:246-255. https://doi.org/ 10.1016/j.foreco.2008.04.032

Fernández-García V, Fulé PZ, Marcos E, Calvo L (2019) The role of fire frequency and severity on the regeneration of Mediterranean serotinous pines under different environmental conditions. Forest Ecol Manag 444:59-68. https://doi.org/10.1016/j.foreco.2019.04.040

Fernández-García V, Marcos E, Fulé PZ, Reyes O, Santana VM, Calvo L (2020) Fire regimes shape diversity and traits of vegetation under different climatic conditions. Sci Total Environ 716:137137. https:// doi.org/10.1016/j.scitotenv.2020.137137

Fréjaville T, Curt T (2015) Spatiotemporal patterns of changes in fire regime and climate: defining the pyroclimates of south-eastern France (Mediterranean Basin). Climatic Change 129:239-251. https://doi.org/10.1007/s10584-015-1332-3

González-Ochoa A, de las Heras J (2002) Effects of post-fire silviculture practices on Pachyrhinus squamosus defoliation levels and growth of Pinus halepensis Mill. Forest Ecol Manag 167:185-194. https:// doi.org/10.1016/S0378-1127(01)00718-6

Granström A (2001) Fire management for biodiversity in the European boreal forest. Scand J Forest Res 16:62-69. https://doi.org/10.1080/ 028275801300090627

Hachmi MH, Sesbou A, Benjelloun H, El Handouz N, Bouanane F (2011) A simple technique to estimate the flammability index of
Moroccan forest fuels. J Combust 2011:1-11. https://doi.org/10. $1155 / 2011 / 263531$

He T, Lamont BB, Downes KS (2011) Banksia born to burn. New Phyto 191:184-196. https://doi.org/10.1111/j.1469-8137.2011.03663.x

He T, Pausas JG, Belcher CM, Schwilk DW, Lamont BB (2012) Fireadapted traits of Pinus arose in the fiery Cretaceous. New Phyto 194: 751-759. https://doi.org/10.1111/j.1469-8137.2012.04079.x

Helluy M, Prévosto B, Cailleret M, Fernandez C, Balandier P (2020) Competition and water stress indices as predictors of Pinus halepensis Mill. radial growth under drought. Forest Ecol Manag 460:117877. https://doi.org/10.1016/j.foreco.2020.117877

Hernández-Serrano A, Verdú M, Santos-del-Blanco L, Climent J, González-Martínez SC, Pausas JG (2014) Heritability and quantitative genetic divergence of serotiny, a fire-persistence plant trait. Annals of botany 114:571-577

Josephs EB, Stinchcombe JR, Wright SI (2017) What can genome-wide association studies tell us about the evolutionary forces maintaining genetic variation for quantitative traits? New Phyto 214:21-33. https://doi.org/10.1111/nph.14410

Keeley JE, Pausas JG (2019) Distinguishing disturbance from perturbations in fire-prone ecosystems. Int J Wildland Fire 28:282-287. https://doi.org/10.1071/WF18203

Keeley JE, Bond WJ, Bradstock RA, Pausas JG, Rundel PW (2011) Fire in Mediterranean ecosystems: ecology, evolution and management. Cambridge University Press, Cambridge

Lamont BB (2020) Evaluation of seven indices of on-plant seed storage (serotiny) shows that the linear slope is best. J Ecol. https://doi.org/ $10.1111 / 1365-2745.13436$

Lamont BB, Enright N (2000) Adaptive advantages of aerial seed banks. Plant Spec Biol 15:157-166. https://doi.org/10.1046/j.1442-1984. 2000.00036.x

Lamont BB, He T (2017) Fire-proneness as a prerequisite for the evolution of fire-adapted traits. Trends in Plant Science 22:278-288. https://doi.org/10.1016/j.tplants.2016.11.004

Lamont BB, Enright NJ, He T (2011) Fitness and evolution of resprouters in relation to fire. Plant Ecol 212:1945-1957. https://doi.org/10. 1007/s11258-011-9982-3

Lamont BB, He T, Downes KS (2013) Adaptive responses to directional trait selection in the Miocene enabled Cape proteas to colonize the savanna grasslands. Evol Ecol 27:1099-1115. https://doi.org/10. 1007/s10682-013-9645-z

Lamont BB, Pausas JG, He T, Witkowski ET, Hanley ME (2020) Fire as a selective agent for both serotiny and nonserotiny over space and time. Crc Cr Rev Plant Sci:1-33

Leech J (1984) Estimating crown width from diameter at breast height for open-grown radiata pine trees in South Australia. Australian Forest Research (Australia)

Martín-Sanz RC, Santos-del-Blanco L, Notivol E, Chambel MR, SanMartín R, Climent J (2016) Disentangling plasticity of serotiny, a key adaptive trait in a Mediterranean conifer. Am J Bot 103:15821591. https://doi.org/10.3732/ajb.1600199

Martín-Sanz RC, Callejas-Díaz M, Tonnabel J, Climent JM (2017) Maintenance costs of serotiny in a variably serotinous pine: the role of water supply. Plos one 12:e0181648

Martín-Sanz RC, San-Martín R, Poorter H, Vázquez A, Climent J (2019) How does water availability affect the allocation to bark in a Mediterranean conifer?. Front Plant Sci 10:607. https://oi.org/10. 3389/fpls.2019.00607

Mitchell RM, Bakker JD (2014) Quantifying and comparing intraspecific functional trait variability: a case study with $\mathrm{H}$ ypochaeris radicata. Funct Ecol 28:258-269. https://doi.org/10.1111/1365-2435.12167

Moreno MV, Conedera M, Chuvieco E, Pezzatti GB (2014) Fire regime changes and major driving forces in Spain from 1968 to 2010. Environ Sci Policy 37:11-22. https://doi.org/10.1016/j.envsci. 2013.08.005 
Mutch RW (1970) Wildland fires and ecosystems-a hypothesis. Ecology 51:1046-1051

Nathan R, Safriel UN, Noy-Meir I, Schiller G (1999) Seed release without fire in Pinus halepensis, a Mediterranean serotinous wind-dispersed tree. J Ecol 87(4):659-669. https://doi.org/10.1046/j.1365-2745. 1999.00382.x

Ne'eman G, Goubitz S, Nathan R (2004) Reproductive traits of Pinus halepensis in the light of fire-a critical review. Plant Ecol 171:69-79

Ne'eman G, Lev-Yadun S, Arianoutsou M (2012) Fire-related traits in Mediterranean basin plants. Israel Journal of Ecol Evol 58:177-194. https://doi.org/10.1560/IJEE.58.2-3.177

Niinemets Ü, Kull O (1995) Effects of light availability and tree size on the architecture of assimilative surface in the canopy of Picea abies: variation in needle morphology. Tree Physiol 15:307-315. https:// doi.org/10.1093/treephys/15.5.307

Nuñez MR, Bravo F, Calvo L (2003) Predicting the probability of seed germination in Pinus sylvestris L. and four competitor shrub species after fire. Annals Forest Sci 60:75-81. 10.1051/forest: 2002076

Oliveira S, Oehler F, San-Miguel-Ayanz J, Camia A, Pereira JM (2012) Modeling spatial patterns of fire occurrence in Mediterranean Europe using Multiple Regression and Random Forest. Forest Ecol Manag 275:117-129. https://doi.org/10.1016/j.foreco.2012. 03.003

Ordoñez JC, Van Bodegom PM, Witte JPM, Wright IJ, Reich PB, Aerts R (2009) A global study of relationships between leaf traits, climate and soil measures of nutrient fertility. Global Ecol Biogeogr 18: 137-149. https://doi.org/10.1111/j.1466-8238.2008.00441.x

Parsons AL, Balch JK, de Andrade RB, Brando PM (2015) The role of leaf traits in determining litter flammability of south-eastern Amazon tree species. Int J Wildland Fire 24:1143-1153. https:// doi.org/10.1071/WF14182

Paula S, Arianoutsou M, Kazanis D, Tavsanoglu C, Lloret F, Buhk C, Ojeda F, Luna B, Moreno J, Rodrigo A (2009) Fire-related traits for plant species of the Mediterranean Basin: Ecological Archives E090-094. Ecology 90:1420-1420. https://doi.org/10.1890/081309.1

Pausas JG (2015a) Evolutionary fire ecology: lessons learned from pines. Trends Plant Sci 20:318-324. https://doi.org/10.1016/j.tplants. 2015.03.001

Pausas JG (2015b) Bark thickness and fire regime. Funct Ecol 29:315327. https://doi.org/10.1111/1365-2435.12372

Pausas JG, Keeley JE (2009) A burning story: the role of fire in the history of life. Bioscience 59:593-601. https://doi.org/10.1525/bio. 2009.59.7.10

Pausas JG, Keeley JE (2014) Evolutionary ecology of resprouting and seeding in fire-prone ecosystems. New Phyto 204:55-65. https:// doi.org/10.1111/nph.12921

Pausas JG, Ribeiro E (2017) Fire and plant diversity at the global scale. Global Ecol Biogeogr 26:889-897. https://doi.org/10.1111/geb. 12596

Pausas JG, Bradstock RA, Keith DA, Keeley JE (2004) Plant functional traits in relation to fire in crown-fire ecosystems. Ecology 85:10851100. https://doi.org/10.1890/02-4094

Pausas JG, Alessio GA, Moreira B, Corcobado G (2012) Fires enhance flammability in Ulex parviflorus. New Phyto 193:18-23

Perry DA, Lotan JE (1979) A model of fire selection for serotiny in lodgepole pine. Evolution 33:958-968

Quintano C, Fernández-Manso A, Calvo L, Marcos E, Valbuena L (2015) Land surface temperature as potential indicator of burn severity in forest Mediterranean ecosystems. Int J appl Earth Obs 36:1-12. https://doi.org/10.1016/j.jag.2014.10.015

Richards CL, Bossdorf O, Muth NZ, Gurevitch J, Pigliucci M (2006) Jack of all trades, master of some? On the role of phenotypic plasticity in plant invasions. Ecol Lett 9:981-993. https://doi.org/ 10.1111/j.1461-0248.2006.00950.x

Romero B, Ganteaume A (2020) Data for "Does recent fire activity impact fire-related traits of Pinus halepensis Mill. and Pinus sylvestris L. in the French Mediterranean area? ". [Data set] Zenodo repository. V2. https://doi.org/10.5281/zenodo.4117707

Romero B, Fernandez C, Lecareux C, Ormeño E, Ganteaume A (2019) How terpene content affects fuel flammability of wildland-urban interface vegetation. Int J Wildland Fire 28:614-627. https://doi. org/10.1071/WF18210

Rosell JA (2016) Bark thickness across the angiosperms: more than just fire. New Phyto 211:90-102. https://doi.org/10.1111/nph.13889

Sahoo S, Subbalakshmi AR, Jolly MR (2020) The fundamentals of phenotypic plasticity. Phenotypic Switching. Elsevier, pp. 1-21. https:// doi.org/10.1016/B978-0-12-817996-3.00001-3

Santoni P, Bartoli P, Simeoni A, Torero J (2014) Bulk and particle properties of pine needle fuel beds-influence on combustion. Int $\mathrm{J}$ Wildland Fire 23:1076-1086. https://doi.org/10.1071/WF13079

Santos del Blanco L, Zas R, Notivol Paíno E, Chambel MR, Majada J, Climent J (2010) Variation of early reproductive allocation in multisite genetic trials of Maritime pine and Aleppo pine. For Syst 19: 381-392

Schmid M, Guillaume F (2017) The role of phenotypic plasticity on population differentiation. Heredity 119:214-225. https://doi.org/ 10.1038/hdy.2017.36

Schröder J, Gadow K (1999) Testing a new competition index for Maritime pine in northwestern Spain. Can J Forest Res 29:280-283

Schwilk DW (2003) Flammability is a niche construction trait: canopy architecture affects fire intensity. The American Naturalist 162:725733. https://doi.org/10.1086/379351

Schwilk DW (2015) Dimensions of plant flammability. New Phyto 206: 486-488. https://doi.org/10.1111/nph.13372

Schwilk DW, Ackerly DD (2001) Flammability and serotiny as strategies: correlated evolution in pines. Oikos 94:326-336

Simeoni A, Thomas J, Bartoli P, Borowieck P, Reszka P, Colella F, Santoni P-A, Torero JL (2012) Flammability studies for wildland and wildland-urban interface fires applied to pine needles and solid polymers. Fire Safety J 54:203-217. https://doi.org/10.1016/j. firesaf.2012.08.005

South DB (1995) Relative growth rates: a critique. South African Forestry J 173:43-48. https://doi.org/10.1080/00382167.1995.9629690

Stephens SL, Libby WJ (2006) Anthropogenic fire and bark thickness in coastal and island pine populations from Alta and Baja California. Journal of Biogeography 33:648-652

Suárez N, Betancor E, Fregel R, Rodríguez F, Pestano J (2012) Genetic signature of a severe forest fire on the endangered Gran Canaria blue chaffinch (Fringilla teydea polatzeki). Conserv Genet 13:499-507

Tapias R, Climent J, Pardos JA, Gil L (2004) Life histories of Mediterranean pines. Plant ecol 171:53-68

Teich A (1970) Cone serotiny and inbreeding in natural populations of Pinus banksiana and Pinus contorta. Can J Bot 48:1805-1809

Tieu A, Dixon K, Meney K, Sivasithamparam K (2001) The interaction of heat and smoke in the release of seed dormancy in seven species from southwestern Western Australia. Ann Bot-London 88:259 265. https://doi.org/10.1006/anbo.2001.1451

Turco M, Rosa-Cánovas JJ, Bedia J, Jerez S, Montávez JP, Llasat MC, Provenzale A (2018) Exacerbated fires in Mediterranean Europe due to anthropogenic warming projected with non-stationary climatefire models. Nature Commun 9:1-9. https://doi.org/10.1038/ s41467-018-06358-z

Varner JM, Kane JM, Kreye JK, Engber E (2015) The flammability of forest and woodland litter: a synthesis. Current Forestry Reports 1: 91-99. https://doi.org/10.1007/s40725-015-0012-x 
Verdú M, Pausas J (2007) Fire drives phylogenetic clustering in Mediterranean Basin woody plant communities. J Ecol 95:13161323. https://doi.org/10.1111/j.1365-2745.2007.01300.x

Vizcaíno-Palomar N, Fady B, Alía R, Raffin A, Mutke S, Garzón MB (2020) The legacy of climate variability over the last century on populations' phenotypic variation in tree height. Sci Total Environ $749: 141454$

Voltas J, Chambel MR, Prada MA, Ferrio JP (2008) Climate-related variability in carbon and oxygen stable isotopes among populations of Aleppo pine grown in common-garden tests. Trees 22:759-769. https://doi.org/10.1007/s00468-008-0236-5

Zhao W, van Logtestijn RS, van Hal JR, Dong M, Cornelissen JH (2019) Non-additive effects of leaf and twig mixtures from different tree species on experimental litter-bed flammability. Plant Soil 436:311324. https://doi.org/10.1007/s11104-019-03931-3

Publisher's note Springer Nature remains neutral with regard to jurisdictional claims in published maps and institutional affiliations. 